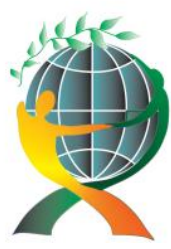

\author{
(online) = ISSN $2285-3642$ \\ ISSN-L = $2285-3642$ \\ Journal of Economic Development, Environment and People \\ Volume 2, Issue 4, 2013 \\ URL: http://jedep.spiruharet.ro \\ e-mail: office jedep@spiruharet.ro
}

\title{
Impact of weight indicators of TOPSIS technique in the selected district in the Slovak Republic
}

\author{
PhDr. Roman Vavrek, doc. Ing. Peter Adamišin, PhD.
}

University of Prešov, Slovakia

\begin{abstract}
The purpose of multicriteria decision models is to help decision maker to evaluate each alternative and to rank them in descending order of performance. This study analyses the concept of Multiple Attribute Decision Making for using in local government area. The aim of this paper is to analyze the concept of Multiple Attribute Decision Making for selecting the most efficient municipality in selected district in the Slovak Republic. Achieving this purpose, TOPSIS technique (in two variants) is used as decision making tools.
\end{abstract}

Keywords: TOPSIS technique, municipality, Prešov district

JEL Codes: H79

\section{Introduction}

According to [5] the aim of multicriteria decision is on a base of chosen criteria to select one variant which shows the best characteristics. However to be successful in this aim needs a huge amount of information which might not be available. Each of methods differs in providing ordinal or cardinal information about the order of each particular variant ( the importance of particular criteria) and whether they need ordinal or cardinal information for its use about particular variants towards particular criteria (about the preference of those criteria). According to [8] the ordinal (order) variable takes verbal value. Those are presenting categories. They have relative meaning because we can't the difference between those categories. That is why you use cardinal (interval) variable which, according to [10] makes quantification. Moreover it makes quantification of differences between the categories.

According to [10] the basic advantage of evaluation on a base of more criteria is the fact, that they do not force reducing non - economic criteria to economic criteria at the expense of precarious or sparing operations.

According to [11] the first step is choosing of objects contained in analyze folder which is followed by choosing of concrete method of more criterion evaluation. Next step is a choosing of characteristics (indicator) characterizing a concrete object, which are considered to be important (the importance of each 


\author{
(online) = ISSN $2285-3642$ \\ ISSN-L = 2285 - 3642 \\ Journal of Economic Development, Environment and People \\ Volume 2, Issue 4, 2013 \\ URL: $\underline{\text { http://jedep.spiruharet.ro }}$ \\ e-mail: office jedep@spiruharet.ro
}

indicator) on a base of subjective preferences of each person individually. The obvious part is the identification of character of each indicator (whether it is the indicator of maximization or the one of minimization).

The process is divided by [5] of more criterion evaluation into following steps:

a) Creating of intentional set of criteria for evaluation with the important characteristics.

b) Making the list of the most important criteria.

c) The evaluation of results (outcomes, profits, and also lacks), variants, consisting of partly evaluation and the synthesis of those partly evaluations.

d) Considering the risk of realization.

e) Making the order list of variants and choosing the most sufficient one.

Other author [2] makes those following methods of more criteria evaluation the ones which are mostly used and also he explains why:

a) Simple method or the method of order summary

b) The method of points

c) The method of standard variable

d) The method of distance of fictive point

Last cited author [9] is describing the two categories of methods of more criteria evaluation of variants:

a) Methods based on partial evaluations of variants

- the method of summary (WSA)

- the method of base variant

b) Methods based on pairs-comparing of variants

- the lexicographical method

- the method AHP (Analytic Hierarchy Process)

- the method TOPSIS (Technique for Order Preference by Similarity to Ideal Solution)

The method of summary is useful when you need to state quantitative criteria. But it expects linear dependence on behalf of criteria (indicators). The principle of base method is stating of the best values and then you are about calculating of each useful function alternative. The lexicographical method consists of the supposal and it is that the biggest influence has the most important criteria. In the case of congruence you observe the second and the next criteria in an order. The method AHP includes all of the factors that influence the result (connection in between and intension of how much they influence each other). The method of TOPSIS is based on choosing a variant which is closest to the one which has been chosen before and also the farthest from the base variant.

The municipality in some part of the Slovak republic was chosen for the purpose of this contemplation and the chosen method was the TOPSIS method. 


\author{
(online) = ISSN $2285-3642$ \\ ISSN-L = 2285 - 3642 \\ Journal of Economic Development, Environment and People \\ Volume 2, Issue 4, 2013 \\ URL: $\underline{\text { http://jedep.spiruharet.ro }}$ \\ e-mail: office jedep@spiruharet.ro
}

\title{
2. TOPSIS technique
}

According to [7] the main concept behind TOPSIS (Technique for Order Preference by Similarity to Ideal Solution), as a technique for solving the Multiple Attribute Decision Making problems, is that the chosen alternative should have the shortest distance from the Positive Ideal Solution, and also have the farthest distance from the Negative Ideal Solution. Positive Ideal Solution is the solution that maximizes the benefit criteria and minimizes the cost criteria, while Negative Ideal Solution is the solution, which maximizes the cost criteria and minimizes the benefit criteria. Furthermore, TOPSIS alleviates the requirement of paired comparisons, and the capacity limitation may not significantly dominate the process. Hence, it is suitable for cases with a large number of attributes and alternatives, and especially handy for objectives with quantitative data.

"It is a rational and relatively simple method where the underlying concept is that the most preferred alternative should not only have the shortest distance from 'ideal' solution, but also the longest distance from an 'anti-ideal' solution." [12]

The other one characteristic by [4] is: "The basic concepts of TOPSIS are based on the predetermined positive ideal solution and negative ideal solution. The purpose is to find the alternative that is closest to positive ideal solution and farthest from the negative ideal solution. The positive ideal solution is the one with the most benefits and lowest cost of all alternatives, the negative ideal solution is the one with the lowest benefits and highest cost."

Series of stages of TOPSIS technique are described by [7] as follows:

a) Construct normalized decision matrix.

b) Construct the normalized weighted decision matrix.

c) Determine the positive ideal and negative ideal solutions.

d) Calculate the separation measures (distance from PIS and NIS for each alternative).

e) Calculate the relative closeness to ideal solution.

f) Rank the preference order.

The same number of stages of TOPSIS techniques is identified by [1] as [7]. They indicate the little more detail 6 stages:

a) Construct the matrix of consequences.

b) Construct the matrix of normalized consequences.

c) Construct the weighted-normalized matrix with the criteria importance coefficients.

d) Define the PIS vector and the NIS vector (the vector for minimal value of alternatives if the criteria is a minimal criteria or the maxim value of alternatives if the criteria is a maxim criteria).

e) Calculation of distance between the each alternative and the positive alternative and the calculation of distance between the each alternative and the negative ideal alternative.

f) Determination of the index to positive ideal solution. 


\author{
(online) $=$ ISSN $2285-3642$ \\ ISSN-L = 2285 - 3642 \\ Journal of Economic Development, Environment and People \\ Volume 2, Issue 4, 2013 \\ URL: http://jedep.spiruharet.ro \\ e-mail: office jedep@spiruharet.ro
}

\title{
3. Methodology
}

Used methods in this article we can divide in three categories:
a) TOPSIS technique,
b) Financial indicators,
c) Statics methods used to municipal valuation.

\subsection{Topsis technique}

According to [3] is the TOPSIS method based on choosing of an alternative, which is closest to the ideal variant and at the same time the farthest from the base variant. The supposal is maximal character of criteria.

We tend to [6], who considers the first step of the method making a matrix of criteria and then the summary of standard matrices. We can describe the calculus as following:

a) Construct starting criterial matrix $\left(\mathrm{y}_{\mathrm{ij}}\right)$ a construction of vector weights $\left(\mathrm{v}_{1}, \mathrm{v}_{2}, \ldots, \mathrm{v}_{\mathrm{k}}\right)$,

b) Construct criterial matrix $\mathrm{R}=\left(\mathrm{r}_{\mathrm{ij}}\right)$ of formula:

$$
r_{i j}=\frac{y_{i j}}{\left(\sum_{i=1}^{n} y_{i j}^{2}\right)^{1 / 2}}
$$

where $i=1,2, \ldots, n ; j=1,2, \ldots, k$.

c) Construct the normalized weighted matrix $\mathrm{W}=\left(\mathrm{w}_{\mathrm{ij}}\right)$ of formula $w_{i j}=v_{j} r_{i j}$, where $\mathrm{y}_{\mathrm{j}}-$ weight of $\mathrm{j}$ criterion.

d) Using the matrix $W$ elements is creating ideal variant $\left(H_{1}, H_{2}, \ldots, H_{k}\right)$ and baseline variant $\left(D_{1}, D_{2}, \ldots\right.$, $\left.D_{k}\right)$, where

where $\mathrm{j}=1,2, \ldots, \mathrm{k}$.

$$
H_{j}=\max \left(w_{i j}\right), D_{j}=\min \left(w_{i j}\right),
$$

f) For the calculation of the distance from the ideal option $\left(d_{i}^{+}\right)$and baseline option $\left(d_{i}^{-}\right)$we use the formula:

where $i=1,2, \ldots n$.

$$
d_{i}^{+}=\left[\sum_{j=1}^{k}\left(w_{i j}-H_{j}\right)^{2}\right]^{1 / 2}, \text { or } d_{i}^{-}=\left[\sum_{j=1}^{k}\left(w_{i j}-D_{j}\right)^{2}\right]^{1 / 2},
$$

g) The last step is calculating a relative distance from baseline variant:

$$
c_{i}=\frac{d_{i}^{-}}{d_{i}^{-}+d_{i}^{+}},
$$

where $i=1,2, \ldots n$. 


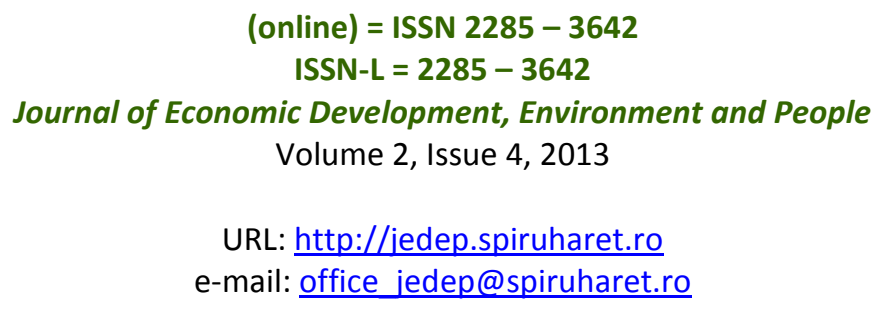

Values $c_{i}$ are in the range $\langle 0 ; 1\rangle$, where 0 represents the basal variant 1 ideal option. The higher the value $c_{i}$, the greater is the distance from the baseline alternatives.

\subsection{Financial indicators}

The described method TOPSIS was used for evaluation of economy in villages belonging to Prešov county (the number of municipalities is 91). The charts consist of chosen villages because of the high number of municipalities in county (just for the illustration of method).

We used for municipal comparison these selected indicators (after consultation with municipalities):

a) $R_{1}$ - total expenditure per capita,

b) $R_{2}$ - borrowed funds to total municipal assets,

c) $R_{3}-$ total income per capita,

d) $R_{4}$ - current profit per capita,

e) $R_{5}$ - return on assets,

f) $R_{6}$ - current expenditure per capita,

g) $R_{7}$ - borrowed funds per capita,

h) $R_{8}$ - current income per capita,

The first indicator $\left(R_{1}\right)$ describes only expenditure (cost $=$ expenditure, i.e. is not examined law compliance) for one financial period per capita:

$$
R_{1}=\frac{C}{P O}
$$

where: $\quad C-$ total expenditure,

$\mathrm{PO}$ - city population.

We can identify the construct of the second indicator $\left(R_{2}\right)$ as follows:

$$
R_{2}=\frac{C z Z}{A},
$$

where: $\quad C z Z-$ borrowed funds,

$$
\text { A - assets. }
$$

The third indicator $\left(R_{3}\right)$ presents total income per capita:

$$
R_{3}=\frac{P}{P O},
$$

where: $\quad \mathrm{P}$-total income, 

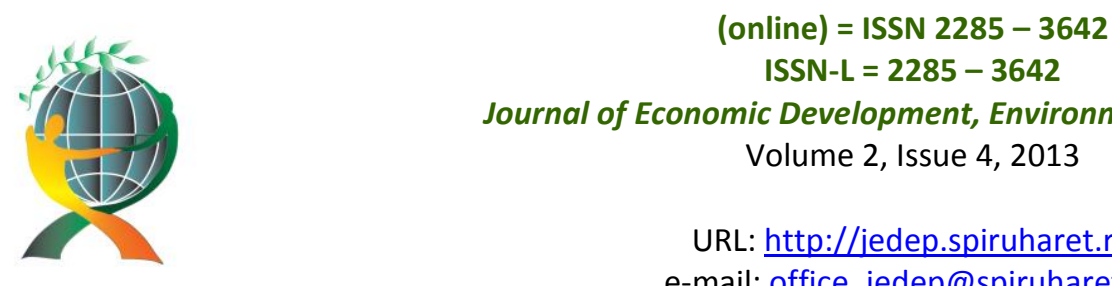

PO - city population.

Current profit per capita in one financial period is the fourth indicator $\left(R_{4}\right)$ that was calculated:

$$
R_{4}=\frac{V H}{P O},
$$

where: $\quad \mathrm{VH}$ - current profit per capita,

$\mathrm{PO}$ - city population.

Return on assets (ROA) presents the fifth indicators $\left(R_{5}\right)$ that is the basic indicator of evaluation of municipal management:

$$
R_{5}=\frac{V H}{A}
$$

where: $\quad \mathrm{VH}$ - current profit per capita,

A - assets.

Current expenditure per capita is the sixth indicator $\left(R_{6}\right)$ that we can calculate:

$$
R_{6}=\frac{C_{B}}{P O}
$$

where: $\quad C_{b}$ - current expenditure,

$\mathrm{PO}$ - city population.

The seventh indicator $\left(R_{7}\right)$ borrowed funds per capita was calculated:

$$
R_{7}=\frac{C z Z}{P O},
$$

where: $\quad \mathrm{CzZ}-$ borrowed funds,

$$
\mathrm{PO} \text { - city population. }
$$

Current income per capita presents the last indicator $\left(R_{8}\right)$ :

$$
R_{8}=\frac{P_{B}}{P O},
$$

where: $\quad \mathrm{P}_{\mathrm{b}}$-current income,

$\mathrm{PO}$ - city population. 


\author{
(online) $=$ ISSN $2285-3642$ \\ ISSN-L = 2285 - 3642 \\ Journal of Economic Development, Environment and People \\ Volume 2, Issue 4, 2013 \\ URL: http://jedep.spiruharet.ro \\ e-mail: office jedep@spiruharet.ro
}

\title{
3.3. Used statistics methods
}

In addition to demonstrations and applications TOPSIS techniques such as multi-criteria evaluation of the effectiveness of the algorithm municipalities, we focus in the next section to analyze the results of multicriteria algorithms.

Municipalities have scored TOPSIS technique quantified of municipality with lowest score were the best. We investigate whether the success factor has a significant effect size of municipality. This leads us to the assumption that the largest of municipality can both realize economies of scale, and have more qualified personnel infrastructure to effectively ensure all processes at of municipality level.

For analysis, we took off in addition to MS excel even further, specialized statistical programs (SPSS and Systat).

Appropriate coefficient to measure context was chosen Kendall-Stuartovo tau-c:

$$
\tau_{\mathrm{c}}=\frac{\mathrm{n}_{\mathrm{c}}-\mathrm{n}_{\mathrm{d}}}{\mathrm{n}^{2}(\mathrm{k}-1) / 2 \mathrm{k}}
$$

where: $\quad n_{c}-$ number of concordant pairs (i.e. ifk $x_{i}>x_{j}$ a $y_{i}>y_{j}$ or $x_{i}<x_{j}$ a $y_{i}<y_{j}$ for each sample consisting of $n$-observations of two variables $Y$ and $Y$ ),

$n_{d}$ - number of disconcordant pairs (i.e. if $x_{i}>x_{j} a y_{i}<y_{j}$ or $x_{i}<x_{j} a y_{i}>y_{j}$ )

$k$ - smaller value of $m, n$.

Both of these coefficients take values from -1 to 1 . High value indicates a high degree of value dependence.

The significance testing of coefficients is based on the calculation of $p$-values. The significance factor is accepted if the calculated $p$-value less than 0,05 .

\section{Results}

Since the method TOPSIS is choosing an alternative which is closest to the ideal variant and at the same time the farthest from the base variant we need to use the character of maximum of spotted indicators. Because of this reason were the indicators $R_{1}, R_{2}, R_{6}, R_{7}$ multiplied by coefficient -1 .

The first step of the TOPSIS method is making a criterion matrix.

Table 1: Criterion matrix in 2012

\begin{tabular}{|l|l|l|l|l|l|l|l|l|}
\hline & $\mathbf{R}_{\mathbf{1}}$ & $\mathbf{R}_{\mathbf{2}}$ & $\mathbf{R}_{\mathbf{3}}$ & $\mathbf{R}_{\mathbf{4}}$ & $\mathbf{R}_{\mathbf{5}}$ & $\mathbf{R}_{\mathbf{6}}$ & $\mathbf{R}_{\mathbf{7}}$ & $\mathbf{R}_{\mathbf{8}}$ \\
\hline Abranovce & $-0,078$ & $-0,010$ & 0,127 & $-0,004$ & $-0,008$ & $-0,109$ & $-0,007$ & 0,104 \\
\hline Bajerov & $-0,181$ & $-0,307$ & 0,190 & 0,007 & 0,012 & $-0,254$ & $-0,251$ & 0,247 \\
\hline Bertotovce & $-0,170$ & $-0,185$ & 0,120 & $-0,024$ & $-0,012$ & $-0,120$ & $-0,531$ & 0,113 \\
\hline Brestov & $-0,056$ & $-0,066$ & 0,058 & 0,000 & 0,000 & $-0,079$ & $-0,033$ & 0,076 \\
\hline Bretejovce & $-0,049$ & $-0,025$ & 0,058 & 0,013 & 0,056 & $-0,068$ & $-0,008$ & 0,065 \\
\hline
\end{tabular}

Source: Own calculations 


\author{
(online) $=$ ISSN $2285-3642$ \\ ISSN-L = $2285-3642$ \\ Journal of Economic Development, Environment and People \\ Volume 2, Issue 4, 2013 \\ URL: http://jedep.spiruharet.ro \\ e-mail: office jedep@spiruharet.ro
}

The criterion matrix (table 1) creates a base for making a standard matrix. This matrix is considering the importance of each particular criterion (indicator), which was studied in two dimensions:

a) each of those indicator has the same weight, means 0,125 ,

b) each of those indicator has weight determined by municipal representatives (table 3 ).

Table 2: Weight ration of financial indicators

\begin{tabular}{|c|c|c|c|c|c|c|c|c|}
\hline & $\mathbf{R}_{\mathbf{1}}$ & $\mathbf{R}_{\mathbf{2}}$ & $\mathbf{R}_{\mathbf{3}}$ & $\mathbf{R}_{\mathbf{4}}$ & $\mathbf{R}_{\mathbf{5}}$ & $\mathbf{R}_{\mathbf{6}}$ & $\mathbf{R}_{\mathbf{7}}$ & $\mathbf{R}_{\mathbf{8}}$ \\
\hline Weight ratio & 0,098 & 0,197 & 0,125 & 0,188 & 0,089 & 0,098 & 0,143 & 0,062 \\
\hline
\end{tabular}

Source: Own calculations

The normalized weighted matrix obtained by weighting the individual indicators contained in table 3 .

Table 3: Normalized weighted matrix in 2012

\begin{tabular}{|l|c|c|c|c|c|c|c|c|}
\hline & $\mathbf{R}_{\mathbf{1}}$ & $\mathbf{R}_{\mathbf{2}}$ & $\mathbf{R}_{\mathbf{3}}$ & $\mathbf{R}_{\mathbf{4}}$ & $\mathbf{R}_{\mathbf{5}}$ & $\mathbf{R}_{\mathbf{6}}$ & $\mathbf{R}_{\mathbf{7}}$ & $\mathbf{R}_{\mathbf{8}}$ \\
\hline \multicolumn{8}{|c|}{ Origin weight rations of financial indicators } \\
\hline Abranovce & $-0,010$ & $-0,001$ & 0,016 & 0,000 & $-0,001$ & $-0,014$ & $-0,001$ & 0,013 \\
\hline Bajerov & $-0,023$ & $-0,038$ & 0,024 & 0,001 & 0,001 & $-0,032$ & $-0,031$ & 0,031 \\
\hline Bertotovce & $-0,021$ & $-0,023$ & 0,015 & $-0,003$ & $-0,002$ & $-0,015$ & $-0,066$ & 0,014 \\
\hline Brestov & $-0,007$ & $-0,008$ & 0,007 & 0,000 & 0,000 & $-0,010$ & $-0,004$ & 0,009 \\
\hline Bretejovce & $-0,006$ & $-0,003$ & 0,007 & 0,002 & 0,007 & $-0,009$ & $-0,001$ & 0,008 \\
\hline \multicolumn{8}{|c|}{ Modify weight ration of financial indicators } \\
\hline Abranovce & $-0,008$ & $-0,002$ & 0,016 & $-0,001$ & $-0,001$ & $-0,011$ & $-0,001$ & 0,006 \\
\hline Bajerov & $-0,018$ & $-0,060$ & 0,024 & 0,001 & 0,001 & $-0,025$ & $-0,036$ & 0,015 \\
\hline Bertotovce & $-0,017$ & $-0,036$ & 0,015 & $-0,005$ & $-0,001$ & $-0,012$ & $-0,076$ & 0,007 \\
\hline Brestov & $-0,006$ & $-0,013$ & 0,007 & 0,000 & 0,000 & $-0,008$ & $-0,005$ & 0,005 \\
\hline Bretejovce & $-0,005$ & $-0,005$ & 0,007 & 0,002 & 0,005 & $-0,007$ & $-0,001$ & 0,004 \\
\hline
\end{tabular}

Source: Own calculations

With the help of elements of standard matrices (table 2) it was created the ideal and baseline variant and then calculated the relative distance from the baseline variant.

Tab. 4: The relative distance from baseline variant in 2012

\begin{tabular}{|l|r|r|}
\hline & Origin & Modify \\
\hline Abranovce & 0,382 & 0,382 \\
\hline Bajerov & 0,279 & 0,232 \\
\hline Bertotovce & 0,232 & 0,220 \\
\hline Brestov & 0,369 & 0,362 \\
\hline Bretejovce & 0,396 & 0,386 \\
\hline
\end{tabular}

Source: Own calculations 


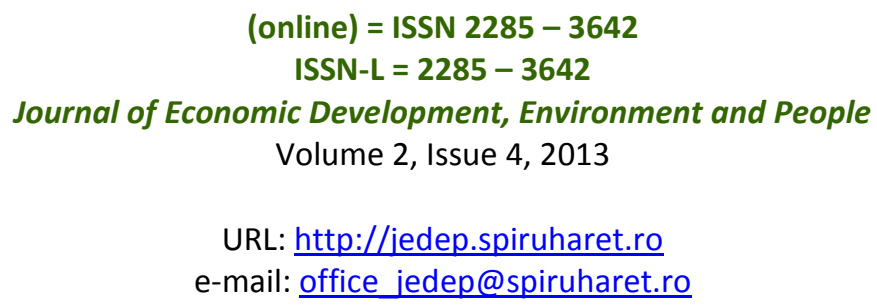

On a base of the relative distance from baseline variant the municipalities were given points and they were arranged in the order for the certain year.

Table 5: The individual score of municipalities in 2012

\begin{tabular}{|l|l|l|}
\hline & Origin rank & Modify rank \\
\hline 1. & Geraltov & Geraltov \\
\hline 2. & Gregorovce & Janov \\
\hline 3. & Janov & Gregorovce \\
\hline & $\ldots$ & \\
\hline 89. & Bajerov & Bajerov \\
\hline 90. & Rokycany & Bertotovce \\
\hline 91. & Bertotovce & Rokycany \\
\hline \multicolumn{3}{|c|}{ Source: Own calculations }
\end{tabular}

The municipality with very little points was classified as the best by the TOPSIS method in the particular section (the years 2010-2012).

Table 6: The overall score of municipalities $2010-2012$

\begin{tabular}{|l|l|r|r|l|r|r|}
\hline & \multicolumn{3}{|c|}{ Origin rank } & \multicolumn{3}{c|}{ Modify rank } \\
\hline & \multicolumn{1}{|c|}{ municipality } & points & PO & municipality & points & PO \\
\hline 1. & Janov & 6 & 304 & Janov & 5 & 304 \\
\hline 2. & Široké & 31 & 2408 & Široké & 35 & 2408 \\
\hline 3. & Záborské & 31 & 584 & Záborské & 19 & 584 \\
\hline & $\ldots$ & $\ldots$ & & & $\ldots$ & $\ldots$ \\
\hline 104. & Šarišské Bohdanovce & 244 & 695 & Šarišské Bohdanovce & 243 & 695 \\
\hline 105. & Chmiňany & 266 & 874 & Chmiňany & 267 & 874 \\
\hline 106. & Bertotovce & 271 & 485 & Bertotovce & 267 & 485 \\
\hline
\end{tabular}

Source: Own calculations

Graph 1 from figure 1 shows the results obtained municipalities by population. 


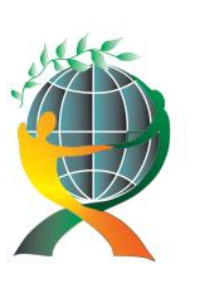

$$
\begin{gathered}
\text { (online) }=\text { ISSN } 2285-3642 \\
\text { ISSN-L = 2285 - } 3642
\end{gathered}
$$

Journal of Economic Development, Environment and People

Volume 2, Issue 4, 2013

URL: http://jedep.spiruharet.ro

e-mail: office jedep@spiruharet.ro
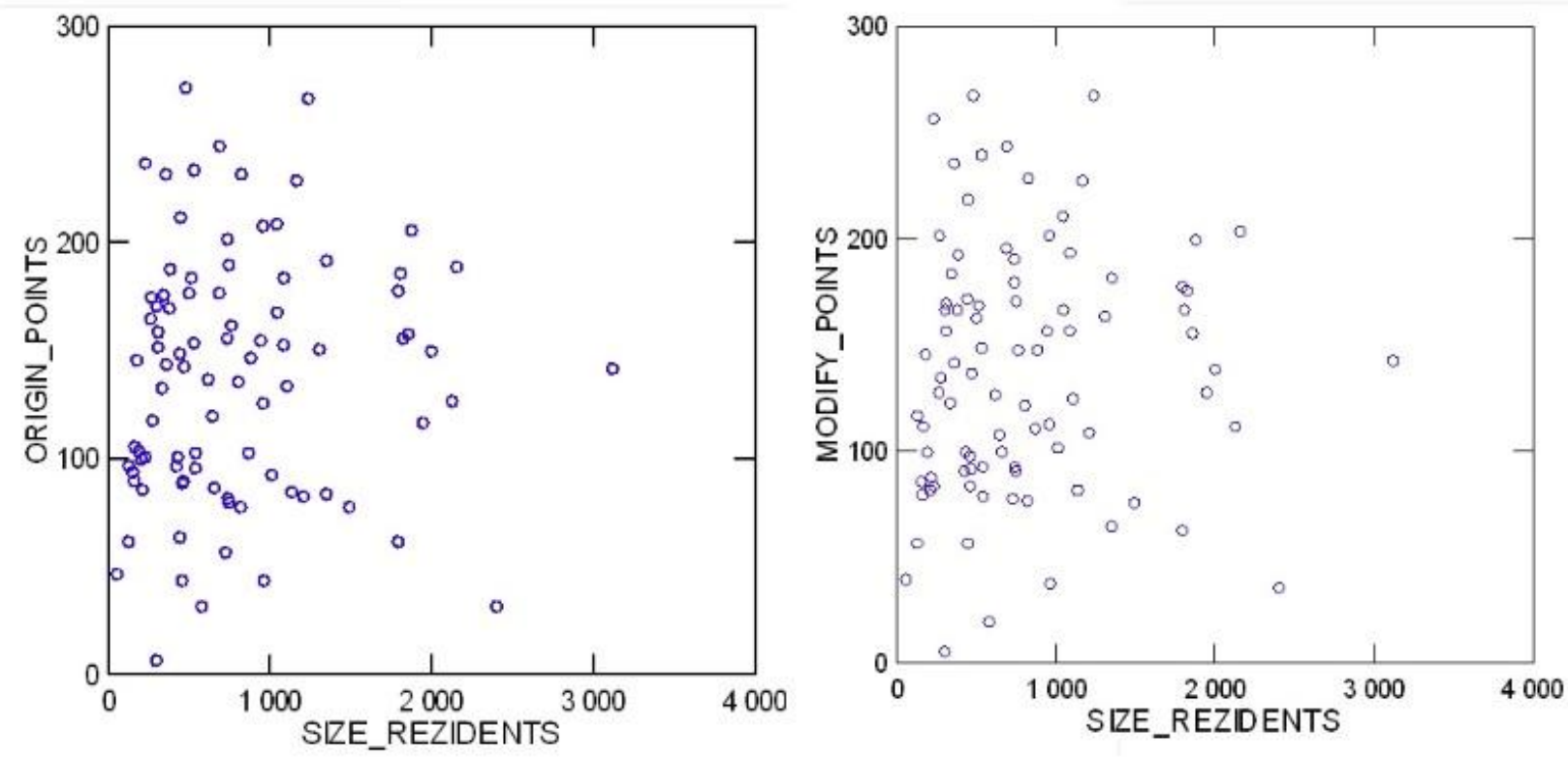

Fig. 1: Scatter plot of parameters the city population and the score

* for better illustration are the city with a population over 5000 eliminated Source: Own calculations

The distribution of the monitored parameters indicates that it is not possible to image by a single regression function. Kendall correlation coefficient more closely monitors a correlation between monitored parameters. Simultaneously, coefficient Kendall-Stuartovo tau-c presents correlation between the score and a municipal size (a city population).

Table 7: Correlation matrix of municipal size and score - origin

\begin{tabular}{|c|l|r|r|}
\hline \multicolumn{2}{|c|}{ Kendall's tau_b } & Size & \multicolumn{1}{l|}{ Score } \\
\hline \multirow{4}{*}{ Municipal size } & Correlation coefficient & 1,000 & 0,120 \\
\cline { 2 - 4 } & Sig. (2-tailed) &. &, 092 \\
\cline { 2 - 4 } & $\mathrm{N}$ & 91 & 91 \\
\hline \multirow{3}{*}{ Score } & Correlation coefficient &, 120 & 1,000 \\
\cline { 2 - 4 } & Sig. (2-tailed) & 0,092 &. \\
\cline { 2 - 4 } & $\mathrm{N}$ & 91 & 91 \\
\hline
\end{tabular}

Source: Own calculations 

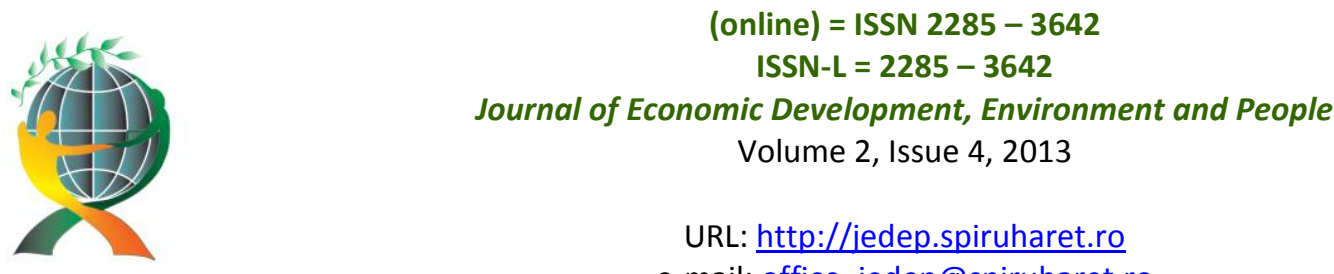

URL: http://jedep.spiruharet.ro

e-mail: office jedep@spiruharet.ro

Table 8: Correlation matrix of municipal size and score - modify

\begin{tabular}{|c|l|r|r|}
\hline \multicolumn{2}{|c|}{ Kendall's tau_b } & Size & Score \\
\hline \multirow{4}{*}{ Municipal size } & Correlation coefficient & 1,000 & 0,133 \\
\cline { 2 - 4 } & Sig. (2-tailed) &. &, 063 \\
\cline { 2 - 4 } & $\mathrm{N}$ & 91 & 91 \\
\hline \multirow{3}{*}{ Score } & Correlation coefficient &, 133 & 1,000 \\
\cline { 2 - 4 } & Sig. (2-tailed) & 0,062 &. \\
\cline { 2 - 4 } & $\mathrm{N}$ & 91 & 91 \\
\hline
\end{tabular}

Source: Own calculations

Reliability calculated parameter does not allow drawing conclusions about the existence of links between those phenomena; even when a statistical confidence level of the correlation coefficient would indicate to statistical inconsistency of the phenomena.

\subsection{Graphical representation of the results}

In the spotted Prešov district was made the ideal variant, means the best values of indicators, which were reached in each of the municipalities in the same year. Following graphical image is describing the year 2012 - the ideal variant with the comparison of results from the best municipality to the worst municipality for the particular year. (fig. 2)

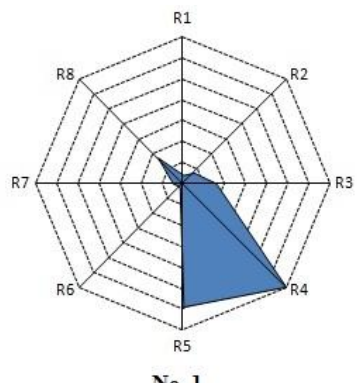

No. 1

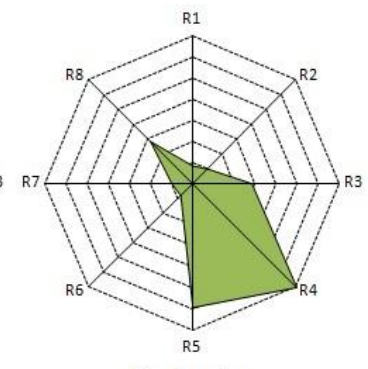

Ideal variant

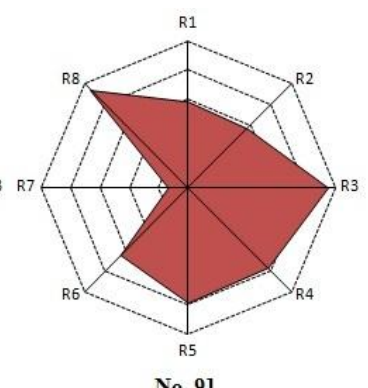

No. 91

Fig. 2: Illustration of results in 2012

Source: Own calculations

The best municipality in Prešov district according to TOPSIS method was Geraltov (0, 843, resp. 0,881) for the year 2012. And the worst one was Bertotovce $(0,232)$. Using modifies weight of indicators - the worst one was Rokycany $(0,200)$.

As you can see the results of both municipalities differ from the ideal (fictive) variant while the deviations are shown in the figure 3 . 
(online) $=$ ISSN $2285-3642$

ISSN-L = $2285-3642$

Journal of Economic Development, Environment and People

Volume 2, Issue 4, 2013

URL: $\underline{\text { http://jedep.spiruharet.ro }}$

e-mail: office jedep@spiruharet.ro

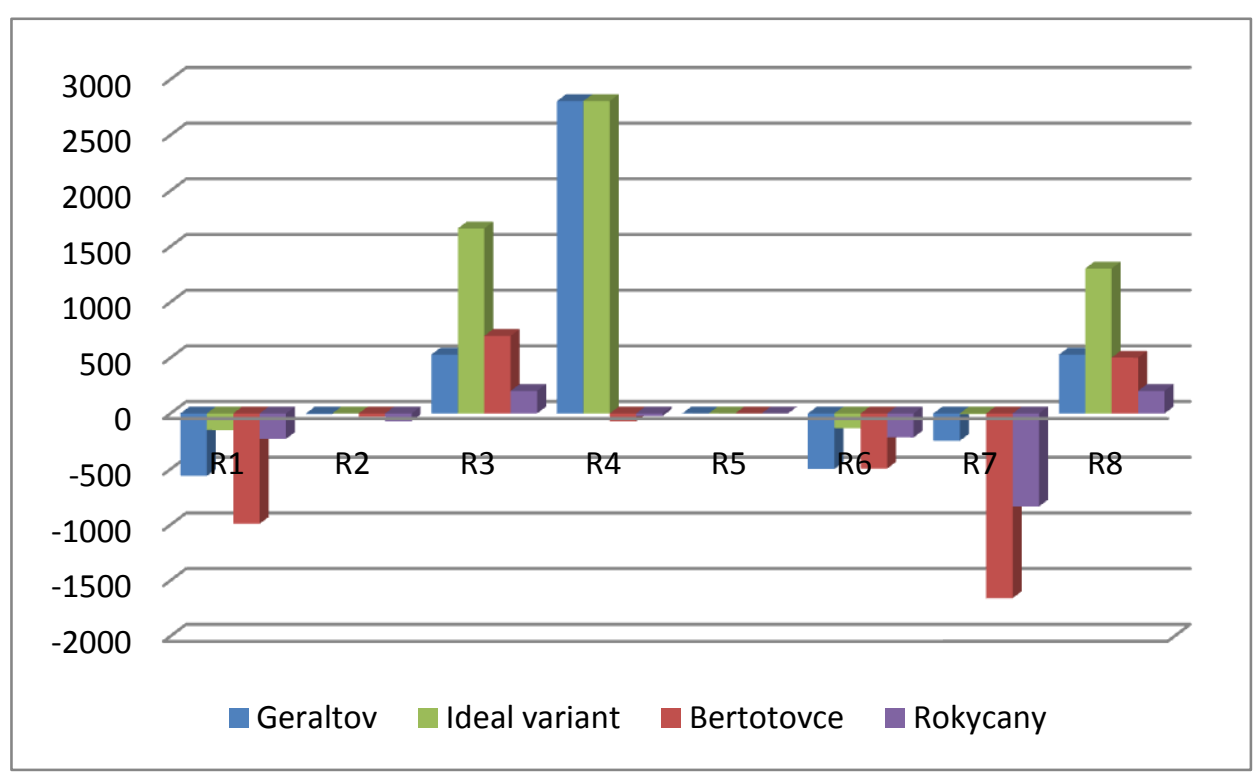

Fig. 3: Indicator comparison of selected municipalities in 2012

Source: Own calculations

\section{Conclusions}

In this study, TOPSIS technique was evaluated and compared using data obtained to assist decision making for selecting the most efficient municipality in selected district in the Slovakia (Prešov district). With the help of 8 chosen indicators it was evaluated the economy of 91 villages in the certain county for the particular section (2010-2012).

On the basis of the research we can conclude that the municipal size and classified by the applied procedures is not a link. Modified weights had an impact on the ranking each year. In order for the whole period 2010 - 2012 these differences were minimal.

TOPSIS and other MADM problem solving techniques can be used as accurate techniques for decision making in public economy. We expect the using of the method to evaluate villages of Prešov district and later also the Slovak republic.

\section{Acknowledgements}

This article was elaborated as a part of grants VEGA 1/0760/13, KEGA 032PU-4/2013 and KEGA 007PU$4 / 2011$. 


\author{
(online) = ISSN $2285-3642$ \\ ISSN-L = $2285-3642$ \\ Journal of Economic Development, Environment and People \\ Volume 2, Issue 4, 2013 \\ URL: $\underline{\text { http://jedep.spiruharet.ro }}$ \\ e-mail: office jedep@spiruharet.ro
}

\title{
7. References
}

[1] ONDOR, C. I., MURESAN, A. 2012.Correlated Criteria in Decision Models: Recurrent Application of TOPSIS Method. In Applied Medical Informatics [online]. 2012. [cit. 2013.10.12]. Available on the internet: $\leq$ http://search.proquest.com/docview/934310759?accountid=14716>.

[2] FABUŠ, M. 2011. Využitie matematicko-štatistických metód vŠVOC. In K rozvoju študentskej vedeckej odbornej činnosti na Ústave ekonomie a manažmentu na VŠEMvs. Bratislava : Vysoká škola ekonomie a manažmentu verejnej správy v Bratislave, 2011. ISBN 9-788097-049591, pp. 9-14.

[3] JABLONSKÝ, J. 2002. Operační výzkum: Kvantitativní modely pro ekonomické rozhodování. 2. vyd. Praha : Professional Publishing, 2002. 323 pp. ISBN 80-86419-23-1.

[4] LING-FENG, H., JIUNG-BIN, CH., MU-CHEN, W., 2006. Performence evaluation for university electronic libraries in Taiwan. In The Electronic Library. [online]. 2010. [cit. 2013.10.13]. Available on the internet:

<http://search. proquest.com/docview/218233243?accountid=14716>.

[5] LIŠTIAK, P. 2012. Konkurencieschopnost́ slovenského hospodárstva vo vztahu k energetike vobdobí finančnej krízy. In . Management Challenges in the 21st Century [online]. 2012. [cit. 2013.10.12]. Available on the internet:

$\leq$ http://www.cutn.sk/Library/proceedings/mch 2012/editovane prispevky/Li\%C5\%A1tiak.pdf>.

[6] MINAŘíK, P. 2010. Porovnání investičních instrumentů - vicekriteriální rozhodování. In Matematika v ekonomické praxi. Jihlava : VŠP Jihlava, 2010. ISBN 978-80-87035-34-4, pp. 121-132.

[7] NOORAMIN, A.S. ET AL. 2012. TOPSIS and AHP techniques for selecting the most efficient marine container yard gantry crane. In Operational Research Society of India [online]. 2012. [cit. 2013.10.12]. Available on the internet:

<http://www.pulib.sk:2088/pqcentral/docview/1017942897/141115FE11FDBD1D61/1?accountid=14716>.

[8] PANCÁKOVÁ, V. 2009. Štatistické metódy pre ekonómov. Bratislava : Ekonóm, 2009. 411 pp. ISBN 978-80-8078284-9.

[9] REKTOŘíK, J. A KOL. 2007. Ekonomika a ř́zení odvětví veřejného sektoru. Praha : Ekopress, 2007. 309 s. ISBN 97880-86929-29-3.

[10] RIMARČíK, M. 2007. Štatistika pre prax. 1. vyd. 2007. 200 pp. ISBN 978-80-969813-1-1

[11] ŠEBO, J. - ŠEBOVÁ, M. 2010. Meranie konkurencieschopnosti viackritériálnym hodnotením. In Journal of Competitiveness 1/2010 [online]. 2010. [cit. 2013.10.12]. Available on the internet: $\leq$ http://www.cjournal.cz/index.php?hid=clanek\&bid=archiv\&cid=23\&cp $=>$.

[12] YILMAZ, B., HARMANCIOGLU, N.B. 2010. Multi-criteria decision making for water ressource management: A case study of the Gediz River Basin, Turkey. In Water S.A. [online]. 2010. [cit. 2013.10.13]. Available on the internet: <http://search. proquest.com/docview/814875563?accountid=14716 . 